ISSN: 2224-0616

Int. J . Agril. Res. Innov. \& Tech. 1(1\&2): 64-68, December, 2011

Available at http:// www.ijarit.webs.com

\title{
DEVELOPMENT OF EFFICIENT CALLUS INITIATION OF MALTA (CitruS sinensis) THROUGH TISSUE CULTURE
}

\author{
Fazle Azim, M.M. Rahman, Shamsul H. Prodhan, Saif U. Sikdar, \\ Nayem Zobayer and M. Ashrafuzzaman*
}

Received 1 November 2011, Revised 24 December 2011, Accepted 25 December 2011, Published online 31 December 2011

\begin{abstract}
The effects of different hormonal concentration on shoot formation and callus induction were studied on BARI Malta-1 (Citrus sinensis). Seeds containing seed coat and without seed coat was treated by Murashige and Skoog (MS) media supplemented with 6-benzyl adenine (BA) and Kinetin (KIN). Removal of seed coat showed an early response for shoot formation. The highest (70\%) shoot formation was obtained from seeds without seed coat treated with MS basal media + BA $1.0 \mathrm{mg} / \mathrm{l}$ while KIN showed no response for shoot formation in any supplemented concentration. However, in case of callus induction internodes and apical shoot tips were used as explants and 2, 4-dichlorophenoxy acetic acid (2, 4-D) was used as callus inducing hormone. MS basal media supplemented with 2, 4-D, $2.0 \mathrm{mg} / \mathrm{l}$ showed highest (68\%) callus induction.
\end{abstract}

Key words: Malta, Citrus sinensis, In vitro, Seed shoot formation, Callus induction

Department of Genetic Engineering \& Biotechnology, Shahjalal University of Science \& Technology, Bangladesh

*Corresponding author's email: azamanbt@ gmail.com

Reviewed by Dr. Iftekhar Ahmad, Shahjalal University of Science \& Technology, Bangladesh

\section{Introduction}

Citrus sinensis is a member of Rutaceae family (Citrus family) and has the common name like sweet orange or naval orange (Christman, 2003) or Malta in Bangladesh. C. sinensis is one of the major commercial fruit crops that is widely consumed both as fresh fruit or juice attributed to its high vitamin $\mathrm{C}$ content and its antioxidant potential (Kiong et al., 2008). As other fruits, citrus is attacked by several pre- and/or post harvest pathogens that affect fruit quality (Bekele, 2007).

Advances in biotechnology have generated new opportunities for citrus genetic improvement. In vitro propagation has therefore been a great potential tool to overcome problems related with the field culture for such species (Hidaka \& Omara, 1989). The genetic improvements of this perennial woody plant often take many years using traditional plant-breeding methods (Kayim and Koe, 2006). Hence, plant tissue culture techniques can be applied as a helpful tool to reduce the time for improvement of Malta through somaclonal variation (Chandler et al., 1996). Techniques like in vitro culture made it easy to improve citrus against different a biotic stresses, low yield and conserve important citrus genotypes though exploiting somaclonal variations, somatic cell hybridization (Kobayashi, et al., 1992; Deng et al., 2000), transformation of high yielding cultivars (Koltunow et al., 2002) disease free plants. But all these highly sophisticated technique requires the presence of highly responsive regeneration protocol.

Through micropropagation method, there is a chance to establish a cell line of virus free Malta or somaclonal varieties. The term somaclonal variation was coined by Larkin and Scowcroft (1981) to define genetic variation present in regenerated plants that is either uncovered or induced by a tissue culture process. Somaclonal variation has been reported in a wide range of traits including plant height, overall growth habit, flower, fruit and leaf morphology, juvenility, maturity date, disease resistance, yield and biochemical characteristics. However, most reports generally deal with either solanaceous or cereal crops and little information has been reported in woody perennial fruit crops.

Sweet orange is well-suited for studies of somaclonal variation because of its biology and efficient performance in tissue culture. Sweet orange plants have been regenerated via somatic embryogenesis from protoplasts isolated from embryogenic callus or suspension cultures, reported by Vardi et al. (1975). Citrus is also very 
responsive organogenically in-vitro, and adventitious buds can be induced in many citrus species from non-meristematic juvenile seedling explants (Grinblat, 1972; Barlass and Skene, 1982). Recently, tissue culture techniques have been adopted for consistent commercial production of economically important plants (Honda et al., 2001). Plant tissue culture technology has been successfully used for the commercial production of microbe free plants (Parmessur et al., 2002).

The present study was done to develop an efficient callus initiation system of Malta (Citrus sinensis) through tissue culture which might be used in genetic transformation system and/or efficient and suitable regeneration protocol of malta in future.

\section{Materials and Methods}

This experiment was conducted at the Plant Genetic Engineering Lab. of the Department of Genetic Engineering and Biotechnology, Shahjalal University of Science \& Technology (SUST), Sylhet, Bangladesh.

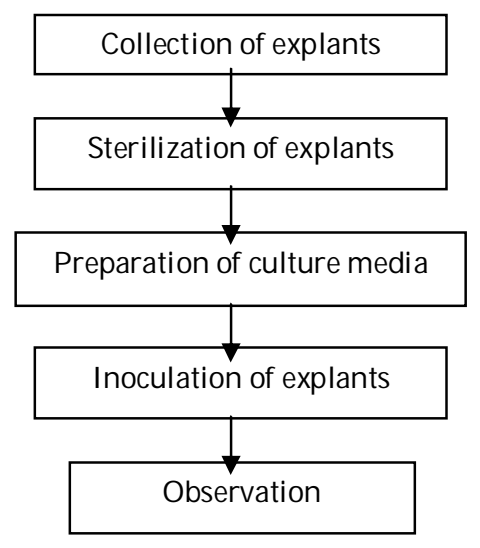

The flow chart of method followed in this experiment

The detail of methods employed during this study is given below:

Collection of explant: The young malta (citrus sinensis) plants were collected from BRAC, Gazipur, Dhaka, Bangladesh before starting this experiment and grown in the pot. The malta seeds were collected from local nursery of Sylhet. The types of explants were seeds, internodes and apical shoot tips. The internodes and apical shoot tips were aseptically excised and cultured on the callus induction medium.

Explant sterilization: Seeds, internodes and shoot tips of C. sinensis were washed by using detergents for 2 minutes. Then explants were immersed for 15 minutes with 2 or 3 drops of Tween-20. In order to remove all traces of detergents and Tween-20 from the surface, explants were washed by sterile-distilled water for 3-4 times.
Shoot formation media: Seed regeneration media were prepared by mixing all the components as the callus induction media except hormones. In case of hormone BA varying in concentration from $1.0 \mathrm{mg} / \mathrm{l}$ to $2.0 \mathrm{mg} / \mathrm{l}$ was used. The other steps i.e., agar melting, autoclaving etc were similar to callus induction media preparation. Explants were inoculated and data were recorded.

Callus induction media: For callus induction popular callus inducing hormone 2, 4-D was used. MS media (Murashige and Skoog, 1962) supplemented with 2, 4-D varying in concentration from $1.0 \mathrm{mg} / \mathrm{l}$ to $3.0 \mathrm{mg} / \mathrm{l}$ were prepared separately in conical flasks. The 3\% sucrose was added to each conical flask. The $\mathrm{P}^{\mathrm{H}}$ was adjusted to 5.6-5.8. Then $0.7 \%$ agar was added. The agar was melted by boiling at $110^{\circ} \mathrm{C}$ for 2-3 minute. After melting the agar, the media were poured into the test-tubes and autoclaved at $121^{\circ} \mathrm{C}$ and $15 \mathrm{psi}$ for 15 minute. After autoclaving the media were allowed to cool down and coagulate in the Laminar Air Flow Cabinet.

Inoculation of explant: Shoot tips and internodes were inoculated in callus induction media. For shoot formation of seeds, some seeds were inoculated with seed coat and some were not. The cultures were incubated at $25 \pm 2^{\circ} \mathrm{C}$ with $16 \mathrm{~h}$ of photoperiod with the light intensity of 2000 lux under cool-white fluorescent lamps. All the treatments were conducted with 5 replicates.

\section{Results and Discussion}

Effect of different concentration of BA and Kinetin on shoot formation: In vitro shoot formation of seed (with seed coat and without seed coat) on MS basal media supplemented with various concentrations of BA and KIN were studied in this experiment. The results of the treatments are summarized in the table 1 . Among all the treatments seeds treated with BA $1.0 \mathrm{mg} / \mathrm{l}$ showed the highest (with seed coat $36 \pm 2.16 \%$ and without seed coat $70 \pm 3.16$ $\%)$ shoot formation (Fig. 1). Other concentrations of BA also showed various degree of response on shoot formation. But KIN showed no response for any kind of concentration.

Effect of seed coat on shoot formation of C. sinensis: C. sinensis contain two layers of seed coat. Some seed were inoculated with seed coat and some were without seed coat. The shoot formation percentage was higher in seeds without seed coat (Fig. 1). This is due to the fact that seed coat is barrier for nutrient passing to the seed. Therefore embryos of the seeds do not get enough nutrients from the surrounding media and thus shoot formation process is delayed. Though seed coat protects embryo from unfavorable environments and microorganisms and helps to survive in nature, it is not necessary for in vitro condition. Rather seed coat is the 
constraint of success for in vitro culture. Neidz (2008) also reported in vitro shoot formation without seed coat. Since aseptic condition is strictly maintained and all microorganisms are eliminated from the culture media seed coat should be removed during inoculation so that embryo can get enough nutrients for shoot formation with a relatively short time and thus percent seed shoot formation without seed coat was increased within a short time. The frequency of shoot proliferation from the germinated seeds without seed coat was higher.

Table 1. Effect of BA and KIN on seed (without seed coat) germination of C. sinensis in MS medium

\begin{tabular}{llll}
\hline Hormone & $\begin{array}{l}\text { Concentration } \\
(\mathrm{mg} / \mathrm{l})\end{array}$ & $\begin{array}{l}\text { Number of explant } \\
\text { inoculated }\end{array}$ & \% of shoot formation (A.M \pm S.E.) \\
\hline \multirow{3}{*}{ BA } & 0.5 & 20 & $64 \pm 2.45$ \\
& 1.0 & 20 & $70 \pm 3.16$ \\
& 1.5 & 20 & $60 \pm 3.16$ \\
& 2.0 & 20 & $40 \pm 4.47$ \\
KIN & 0.5 & 20 & No shoot formation \\
& 1.0 & 20 & No shoot formation \\
& 1.5 & 20 & No shoot formation \\
& 2.0 & 20 & No shoot formation \\
\hline
\end{tabular}

Here, A.M. = Arithmetic Mean and S.E.=Standard Error

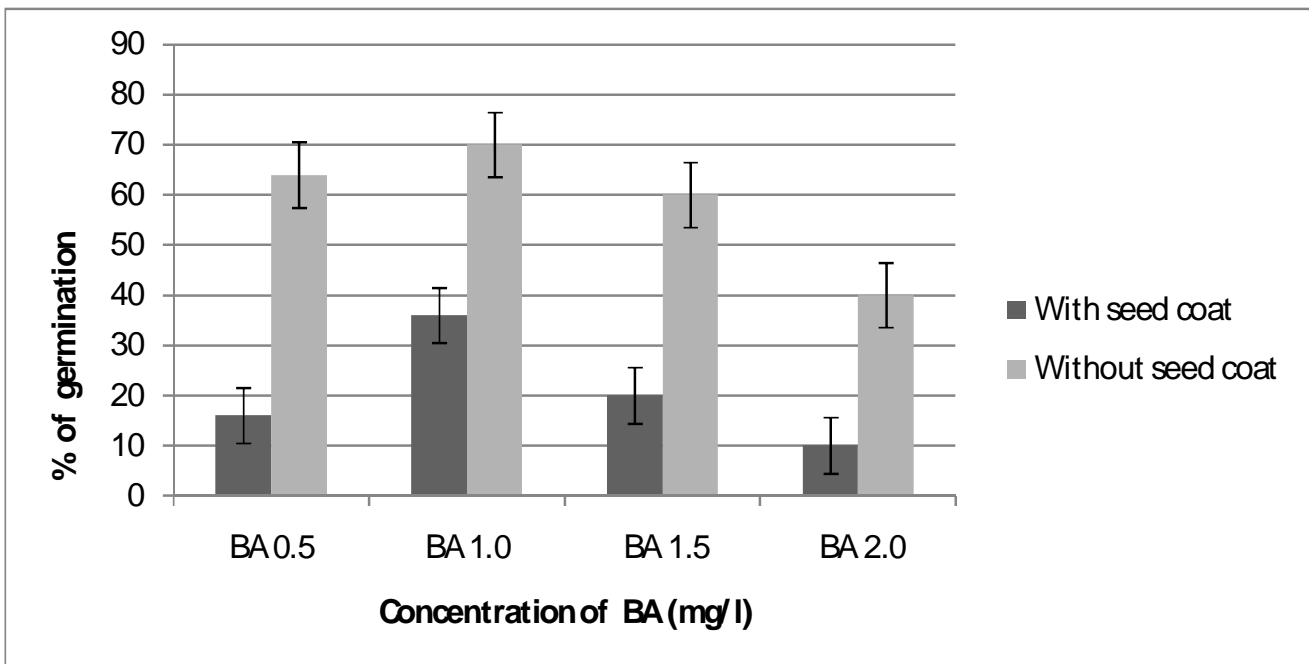

Fig. 1. Effect of seed coat on the shoot formation of C. sinensis. MS media supplemented with BA 1 $\mathrm{mg} / \mathrm{l}$ showed best response for shoot formation where removal of seed coat showed $70 \pm 3.16 \%$ and seeds containing seed coat showed $36 \pm 2.16 \%$ shoot formation

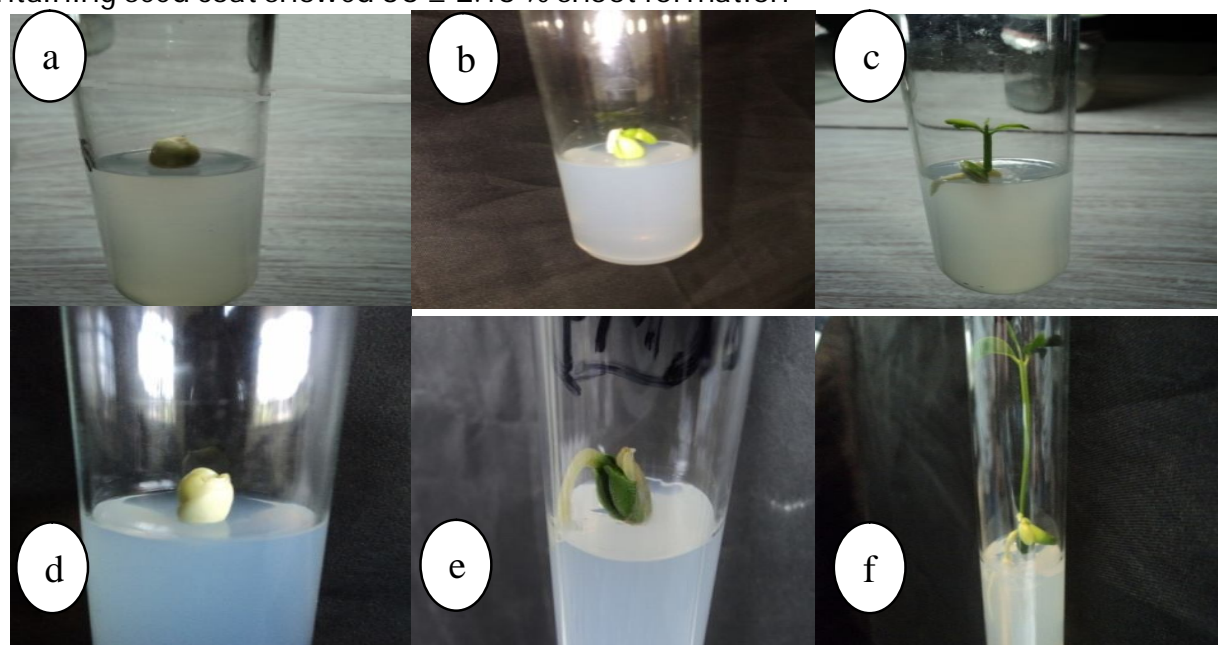

Fig. 2. Shoot formation of C. sinensis where a, b, c representing the poor shoot formation of seed containing seed coat and d, e, f representing the rapid shoot formation of seed without seed coat. In each case seeds were treated with MS basal media supplemented with BA $1.0 \mathrm{mg} / \mathrm{l}$. 
Effect of different concentration of 2, 4-D on callus induction: Response of $2,4-\mathrm{D}$ on callus induction by internodes and shoot tips as explants was studied. Effects of 2, 4-D on callus induction is showed in the table 2 . The highest percent ( $68 \pm 2.00 \%$ ) callus was obtained from 2 , $4-\mathrm{D}, 2 \mathrm{mg} / \mathrm{l}$. This result is contradictory in the concentration of 2, 4-D with Kiong et al. (2008).
During study of somatic embryogenesis Kiong et al. (2008) reported that 2, 4-D, $4.0 \mathrm{mg} / \mathrm{l}$ and 2 , 4-D 3mg/l showed highest percent callus induction. But they also found 2, 4-D, $2.0 \mathrm{mg} / \mathrm{l}$ showed a good response. However, we also found that 2, 4-D, $1.0 \mathrm{mg} / \mathrm{l}$ and 2, 4-D, $3.0 \mathrm{mg} / \mathrm{l}$ also showed a moderate response. The callus induction from explants is showed in figure 3.

Table 2. Effect of 2, 4-D on callus induction from nodal segment of C. sinensis. 2, 4-D, $2.0 \mathrm{mg} / \mathrm{l}$ showed the best response for callus induction

\begin{tabular}{llllll}
\hline $\begin{array}{l}\text { Concentration } \\
\text { of 2,4-D } \\
(\mathrm{mg} / \mathrm{l})\end{array}$ & $\begin{array}{l}\text { Number of } \\
\text { explant } \\
\text { inoculated }\end{array}$ & $\begin{array}{l}\text { Number of } \\
\text { explant survived }\end{array}$ & $\begin{array}{l}\text { Survival } \\
\text { rate }\end{array}$ & $\begin{array}{l}\text { Number of } \\
\text { explants that give } \\
\text { rise to callus }\end{array}$ & $\begin{array}{l}\text { Percent of callus } \\
\text { induction (A.M. } \pm \\
\text { S.E.) }\end{array}$ \\
\hline 1.0 & 25 & 20 & $80 \%$ & 12 & $60 \pm 4.47$ \\
2.0 & 25 & 25 & $100 \%$ & 17 & $68 \pm 2.00$ \\
3.0 & 25 & 20 & $80 \%$ & 13 & $65 \pm 2.44$ \\
\hline
\end{tabular}

Here, A.M.=Arithmatic mean and S.E. = Standard error
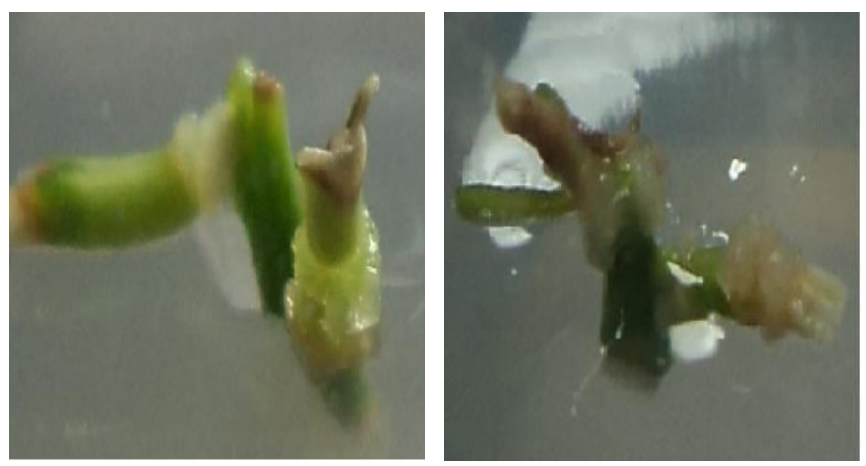

Fig. 3. Callus induction from nodal segment of C. sinensis. MS media supplemented with 2, 4-D $2.0 \mathrm{mg} / \mathrm{l}$ showed best ( $68 \pm 2.00 \%$ ) response for callus induction

\section{Acknowledgement}

The authors are grateful to the authority of National Museum of Science and Technology, Agargaon, Dhaka, Bangladesh for their financial support to carry out this study.

\section{References}

Barlass, M. and Skene, K.G.M. 1982. In vitro plantlet formation from Citrus species and hybrids. Scientia Horticulturae, 17(4): 333341.

Bekele, S. 2007. Identification of citrus (Citrus sinensis) postharvest pathogens from ethiopia and their control. Ph.D. Thesis. University of Pretoria.

Chandler, L.J., Gmitter, F.G. and Grosser, J.W. 1996. Somaclonal variation in sweet orange a tool for cultivar improvement. Proc. Int. Soc. Citriculture, 1: 203.

Christman, S. 2003. Citrus sinensis. URL: http:/ / www.florida.com/ref/c/citr_sin.cfm. Accessed on $6^{\text {th }}$ june 2006.
Deng, X.X., Yu, G.H. and Guo, W.W. 2000. Somatic hybridization between diploids and allotetraploid somatic hybrids in Citrus. 9th ISC Congress Sun City Resort, South Africa, 54: 115- 21

Grinblat U., 1972. Differentiation of citrus stem in vitro. J. American Soc. Horti. Sci., 97(5): 599-603.

Hidaka, T. and Omura, M. 1989. Control of embryogenesis in citrus cell culture regeneration protoplasts and attempts to callus bank. Bulletinof the Fruit tree Research Station, Series Okitsu, 16: 1- 17.

Honda H., Liu C.Z and Kobayashi T. 2001. Large-scale plant micropropagation. Adv. Biochem. Eng. Biotech. 72: 158-182.

Kayim, M. and Koe, N.K. 2006. The effects of some carbohydrates on growth and somatic embryogenesis in citrus callus culture. Scientia Horticulturae, 109: 29-34.

Kiong, A.L.P., Wan, L.S., Hussein, S. and Ibrahim, R. 2008. Induction of somatic embryos from explants different of Citrus sinensis. J. Sci., 3: 18-32. 
Kobayashi, S. 1992. The production of novel cultivars of fruit trees using protoplast fusion. Res. J . Food and Agric., 15: 16- 20.

Koltonow, A.M. 2002. Regeneration of West Indian Limes (Citrus aurantifolia) Containing genes for decreased seed set. Acta Hort., 535: 151- 157.

Larkin, P.J. and Scowcroft, W.R. 1981. Somaclonal variation- a novel source of variability from cell cultures for plant improvement. Theoritical and Applied Gen., 60: 197-214.

Murashige, T. and Skoog, F. 1962. A revised medium for rapid growth and bioassays with tobacco tissue cultures. Physiologia Plantarum, 15: 473-497.

Niedz R.P. 2008. In vitro germination of Citrus seed. Proceedings of the Florida State Horticultural Society, 21: 148-151.

Parmessur, Y.S., Alijanabi, S., Saumatally, S. and Dookun-Samutually, A. 2002. Sugarcane yellow virus and sugarcane yellow phytoplasma: elimination by tissue culture. Plant Pathol. 51: 561-569.

Vardi, A., Spiegel-Roy, P. and Galun, E. 1975. Citrus cell culture: isolation of protoplasts, plating densities, effect of mutagenes and regeneration of embryos. Plant Science Letters, 4: 231-236. 